\title{
Assessment of cytotoxic and antimicrobial activity of selected gingival haemostatic agents - in vitro study
}

\author{
MARIA SZYMONOWICZ ${ }^{1}$, AGNIESZKA RUSAK ${ }^{2 *}$, MAGDALENA PAJĄCZKOWSKA ${ }^{3}$, JOANNA NOWICKA ${ }^{3}$, \\ KAMILA WIŚNIEWSKA ${ }^{1}$, BOGUSŁAWA ŻYWICKA ${ }^{1}$, ZBIGNIEW RYBAK ${ }^{1}$, MACIEJ DOBRZYŃSKI ${ }^{4}$ \\ ${ }^{1}$ Department of Experimental Surgery and Biomaterials Research, Faculty of Dentistry, \\ Wroclaw Medical University, Wrocław, Poland. \\ ${ }^{2}$ Department of Human Morphology and Embryology, Division of Histology and Embryology, Faculty of Medicine, \\ Wroclaw Medical University, Wrocław, Poland. \\ ${ }^{3}$ Department and Division of Microbiology, Faculty of Medicine, Wroclaw Medical University, Wrocław, Poland. \\ ${ }^{4}$ Department of Conservative Dentistry and Pedodontics, Faculty of Dentistry, Wroclaw Medical University, Wrocław, Poland.
}

\begin{abstract}
Purpose: The present research aimed to determine whether and how the aluminium chloride - based materials affect the cell line of the bacterial line and fungi. Methods: Cytotoxicity of haemostatic astringents: Alustat (liquid), Alustat (gel), Alustat (foam), Alustin, Hemostat, Racestyptine and Traxodent containing $\mathrm{AlCl}_{3}$ was conducted on $\mathrm{L} 929$ cell line with the use of MTT and SRB assays. The antimicrobial activity (CFU and MIC) against C. albicans, S. mutans, L. rhamnosus was determined. Results: In the MTT results, cell viability for all agents were very low. In SRB, the lowest cytotoxicity was demonstrated for Hemostat and Alustat (foam), Traxodent and Racestyptine. Total reduction of the CFU of $S$. mutans was observed. Alustat (gel) and Alustat (liquid) completely inhibited the growth of C. albicans, S. mutans and L. rhamnosus. Conclusions: The viability of L929 cells obtained in the SRB assay is more reliable than that obtained in the MTT assay, in the case of gingival haemostatic agents.
\end{abstract}

Key words: haemostatic agents, cytotoxicity, gingiva retraction, antimicrobial activity

\section{Introduction}

Damage to the mucosa of the oral cavity may be caused by the activity of external iatrogenic factors or systemic disorders. Soft tissues are frequently injured while working on carietic defects, during tooth preparation for permanent prosthetic restoration, removal of tartar or exsection of small fragments of the gingiva; the injury causes gingival bleeding [3], [16], [24]. Retraction of the marginal gingiva is frequently performed during the procedures associated with the processes of reconstructing the lost hard tissue of the tooth. Retraction threads, soaked in various substances in the form of solutions, gels or a retraction paste, which show haemostatic effect, are most often used for this purpose. These agents are used to stop the bleeding during the planned cutting of a small fragment of the marginal gingiva or a hypertrophic gingival papilla in a carietic defect, in the cases of bleedings from the pulp during the treatment of its inflammation with the use of intravital methods. Products with direct haemostatic effect on the gingiva, containing various chemical compounds, are used to quickly stop the bleeding in the oral cavity.

The market offers a wide range of products for local haemostasis during dental procedures. It is done with the use of astringents and vasoconstrictive sub-

\footnotetext{
* Corresponding author: Agnieszka Rusak, Department of Human Morphology and Embryology, Division of Histology and Embryology, Wroclaw Medical University, ul. T. Chałubińskiego 6a, 50-368 Wrocław, Poland. Phone: +48 71 784-13-54, fax: +48 71 784-00-82, e-mail: agnieszka.rusak@umed.wroc.pl

Received: May 16th, 2020

Accepted for publication: July 16th, 2020
} 
stances. They differ in colour and consistency, which results from the composition of a chemical preparation and the active substances contained in it. Astringents are aqueous solutions of metal ions. They show drying effect and, as a result of serum protein precipitation, they close the lumen of minor blood vessels. Astringents include: aluminium chloride, aluminium sulphate, iron sulphate, potassium aluminium sulphate or tanninic acid. The agents constricting capillaries include adrenaline in the concentration of $0,005 \mathrm{mg} / \mathrm{ml}$ to $0,033 \mathrm{mg} / \mathrm{ml}$. They act on alpha- and beta-adrenergic receptors of blood vessels [1], [3], [16].

Aluminium chloride is the most frequently used component of haemostatic agents. It is cheap, easy to use and can be stored at room temperature [22]. The mechanism of its activity consists of a hydrolysis to hydrogen chloride, which results in protein coagulation in the superficial layer of the damaged or undamaged gingival tissue, vasoconstriction and activation of the exogenous coagulation pathway. In higher concentrations (over 10\%), aluminium chloride may cause tissue damage [12], [25]. In contact with blood, kaolin, which is present in some agents, shows hygroscopic expansion [1]. The agents can be found in the form of liquids, gels and foams. The fact that liquid agents cannot be used in a particular area in a precise manner constitutes their disadvantage. On the other hand, products in the form of gel or foam can be applied precisely in a selected area, without risking the spillage of the preparation onto the surrounding tissues and their possible damage. Moreover, more firm consistency makes it possible to visually assess the area covered by the preparation applied onto the tissue.

Apart from stopping the gingival bleeding during dental and prosthetic procedures, haemostatic agents are used for the purposes of retracting the gingiva. The retraction threads are used by as many as $98 \%$ of dentists; $81 \%$ of those threads are soaked in haemostatic material, out of which $55 \%$ are soaked in aluminium chloride [5]. The application of haemostatic and retraction measures is generally aimed at ensuring the best quality of the conducted procedure, biocompatibility of the materials used with the periodontium as well as durability of the fillings. In the case of the chemical agents used in the oral cavity, including the ones used for haemostasis and the retraction of the gingiva, the dentist must remember about the safety of their side effects, both local - on the dental tissues and the tissues of the marginal gingiva (damages, discolorations) - and systemic.

Astringents, the factors which effectively stop the bleeding through serum and tissue protein precipita- tion, may cause temporary damage to the gingival tissue and destruction of the dentine. Moreover, due to low $\mathrm{pH}$, some haemostatic factors, such as $21.3 \%$ aluminium chloride, $8 \%$ epinephrine and $15.5 \%$ iron sulphate are the cause of activity destroying the dental and periodontal tissues [12]. Salts of all metals may also cause the occurrence of general symptoms associated with hypersensitivity to those drugs. In the case of aluminium chloride used in concentrations of up to $20 \%$, no systemic reactions are described. Therefore, while using threads impregnated with haemostatics, one must consider not only their physical properties, but also the type and concentration of the chemical agent they have been soaked in [12], [20].

Reconstructive dentistry strives for perfect restoration of hard dental tissue, which is not always fully satisfactory. The formation of a marginal gap leads to microbial microlekeage, penetration of microorganisms into the gap and is conducive to secondary caries development. Both the manufacturers of haemostatic agents and clinicians strive to develop systems and procedures decreasing the risk of microleakage.

The currently available haemostatics are not fully biocompatible with the periodontal tissues, therefore studies aimed at obtaining haemostatic agents with optimal biological properties are still being carried out. While selecting the haemostatic measure or gingival retraction threads, one should consider not only their local effectiveness, but also the possible side effects. The degree of biocompatibility, the stability of the material in the body fluids and its direct effect on cells are associated with the structure, form, and chemical composition of the material.

The authors undertook research aimed at determining whether and how the aluminum chloride-based materials affect the cell line and the bacterial strains and fungi.

\section{Materials and methods}

\subsection{Haemostatic agents}

Commercially available dental agents from the astringent group with haemostatic properties were selected for the study [20]. The selected agents varied in form and chemical composition with basic substance, aluminium chloride. The studies were conducted on the following agents: Alustat (gel), Alustat (liquid), Alustat 
Table 1. Characteristics of selected hemostatic agents.

$\mathrm{AlCl}_{3}$ - aluminium chloride; quinosol - 8-hydroxyquinoline sulfate

\begin{tabular}{|l|l|l|l|}
\hline \multicolumn{1}{|c|}{ Medicament } & Active ingredients & \multicolumn{1}{|c|}{$\begin{array}{c}\text { Ancillary } \\
\text { component }\end{array}$} & \multicolumn{1}{|c|}{ Manufactures } \\
\hline Alustat (liquid) & $25 \% \mathrm{AlCl}_{3} * 6 \mathrm{H}_{2} \mathrm{O}$ & quinosol & Cerkamed, Nisko, Poland \\
\hline Alustat (gel) & $25 \% \mathrm{AlCl}_{3} * 6 \mathrm{H}_{2} \mathrm{O}$ & quinosol & Cerkamed, Nisko, Poland \\
\hline Alustat (foam) & $20 \% \mathrm{AlCl}_{3} * 6 \mathrm{H}_{2} \mathrm{O}$ & kaolin & Cerkamed, Nisko, Poland \\
\hline Alustin (liquid) & $20 \% \mathrm{AlCl}_{3} * 6 \mathrm{H}_{2} \mathrm{O}$ & quinosol & Chema, Rzeszów, Poland \\
\hline Hemostat (gel) & $20 \% \mathrm{AlCl}_{3} * 6 \mathrm{H}_{2} \mathrm{O}$ & quinosol & $\begin{array}{l}\text { Chema, Rzeszów, Poland } \\
\text { France }\end{array}$ \\
\hline Racestyptine (liquid) & $25 \% \mathrm{AlCl}_{3} * 6 \mathrm{H}_{2} \mathrm{O}$ & oxyquinosol & $\begin{array}{l}\text { potassium nitrate, potassium } \\
\text { sorbate, montmorillonite }\end{array}$ \\
\hline Traxodent (paste) & $15 \% \mathrm{AlCl}_{3} * 6 \mathrm{H}_{2} \mathrm{O}$ & $\begin{array}{l}\text { Premier Dental Products Co., } \\
\text { Plymouth Meeting, PA }\end{array}$ \\
\hline
\end{tabular}

(foam), Alustin (liquid), Hemostat (gel), Racestyptine (liquid), Traxodent (paste). The characteristics of the agents are presented in Table 1.

\subsection{Preparation of extract}

Twenty-four hours before the beginning of the tests, extracts for each tested haemostatic preparation and the control samples were prepared. The materials were extracted for $24 \mathrm{~h}$ at $37{ }^{\circ} \mathrm{C}$, HERAcell $\mathrm{CO}_{2}$ Incubator $150 \mathrm{i}$, in a complete culture medium with an addition of FBS. The following amounts of the tested material were assumed for the extracts from agents: $0.1 \mathrm{~g} / \mathrm{ml}$ medium $(1: 5)$ and $0.2 \mathrm{~g} / \mathrm{ml}$ medium (1:10). Subsequent dilutions $(1: 10,1: 20,1: 40)$ were dilutions of the primary extract in a complete culture medium.

An extract from HDPE (high-density polyethylene, United States Pharmacopeia (USP) Reference Standard, Sigma-Aldrich) constituted the negative control in the study in concentration $0.2 \mathrm{~g} / \mathrm{ml}$ of the medium (1:5). SLS (sodium lauryl sulfate, SigmaAldrich) solutions in a complete culture medium, in concentrations of $0.2,0.15,0.1$ and $0.05 \mathrm{mg} / \mathrm{ml}$, constituted the positive control. A cell culture in a complete medium (blank test) and as well as culture fluid without the presence of cells were included into the study as a control.

\section{3. $\mathrm{pH}$ determination}

The $\mathrm{pH}$ determination was assessed for each hemostatic agents, extracts and their dilutions (1:10, 1:20 and 1:40), negative control (HDPE extract), SLS solutions (positive control), as well as full EMEM medium. Measurements were made using a $\mathrm{pH}$ meter (Mettler
Toledo Seven Easy, Warsaw, Poland) and alkacimetric indicators.

\subsection{In vitro cytotoxicity}

\subsubsection{Cell line}

The studies were conducted on normal cells of mouse fibroblasts in line L929 (NCTC clone 929: CCL1, American Type Culture Collection ATCC ${ }^{\circledR}$, Old Town Manassas, VA, USA), which is one of the reference cell lines in the in vitro assessment of biomaterial cytotoxicity [19]. The culture of L929 cells was conducted with the EMEM (Eagle's Minimum Essential Medium) medium with $4.5 \mathrm{~g} / \mathrm{l}$ of glucose, $25 \mathrm{mM}$ of HEPES (Corning, New York, NY, USA) with an addition of $1 \%$ of L-glutamine with streptomycin and penicillin (Sigma-Aldrich, St. Louis, MO, USA) and $10 \%$ of FBS (Fetal Bovine Serum, Sigma Aldrich) in standard conditions: at $37{ }^{\circ} \mathrm{C}, 5 \%$ of $\mathrm{CO}_{2}$ with constant air humidity in HERA cell $\mathrm{CO}_{2}$ Incubator $150 \mathrm{i}$ (Thermo Scientific, Waltham, MA, USA).

\subsubsection{Test preparation}

The cells were trypsinised (0.25\% Trypsin - EDTA (ethylenediaminetetraacetic), Sigma-Aldrich) and plated out on a 96-well plate (Falcon, New York, NY, USA) in the amount of $1.0 \times 10^{4}$ cells/well in $100 \mu 1$ of a complete culture medium. After $24 \mathrm{~h}$, the culture medium was poured out and $100 \mu \mathrm{l}$ of the studied extracts, diluted in the complete medium (1:5, 1:10, $1: 20$, or 1:40) were placed in the wells; $100 \mu 1$ of the SLS solution (Sigma-Aldrich) in the concentration of $0.2,0.15$ or $0.05 \mathrm{mg} / \mathrm{ml}, 100 \mu \mathrm{l}$ of the extract from HDPE (Sigma-Aldrich) and $100 \mu 1$ of the complete medium were placed in the other wells. Experiments were provide in triplicate. 


\subsubsection{Evaluation of cell morphology}

Prior to the MTT and SRB assays, morphology of cells was evaluated with the use of the inverted contrastphase microscope CKX-41 (Olympus, Tokyo, Japan). The morphology of cell culture was assessed in terms of the changes in the shape of cells, the continuity of cell membrane, the occurrence of lysis, changes in cell nuclei and inhibition of culture growth [19].

\subsubsection{MTT assay}

Twenty-four hours after the placement of the plate with the extracts in the 1:5, 1:10 and 1:20 solutions, the extracts and medium were poured out, and $50 \mu 1$ of the MTT solution (3-(4,5-dimethylthiazol-2-yl)-2,5-diphenyltetrazolium bromide, Sigma Aldrich) at $1 \mathrm{mg} / \mathrm{ml}$ concentration was placed in each well and incubated for $2 \mathrm{~h}\left(37^{\circ} \mathrm{C}, 5 \%\right.$ of $\left.\mathrm{CO}_{2}\right)$. Then, the MTT solution was poured out and $100 \mu \mathrm{l}$ of DMSO (dimethyl sulfoxide, Sigma-Aldrich) was added to each well. After $30 \mathrm{~min}$ the absorbance at $570 \mathrm{~nm}$ wavelength was read with the use of microplate reader (ELx 800, BIO-TEK Instruments, Winooski, VT, USA) [14], [19], [20].

\subsubsection{SRB assay}

Twenty-four hours after the placement of the plate with dressings in the 1:10, 1:20 and 1:40 solutions, $50 \mu \mathrm{l}$ of $50 \%$ cold trichloroacetic acid (TCA, Sigma-Aldrich) was added to each well and incubated for $1 \mathrm{~h}$ at $4{ }^{\circ} \mathrm{C}$. The plate was then rinsed with water, dried, and $50 \mu 1$ of $0.4 \%$ solution of sulforhodamine B (SRB, Sigma-Aldrich) in 1\% acetic acid (Sigma-Aldrich) was added to each well. After $30 \mathrm{~min}$ of incubation RT (Room Temperature), the plate was rinsed 5 times with $1 \%$ acetic acid (Sigma-Aldrich), dried and $150 \mu 1$ of $10 \mathrm{mM}$ TRIS (Hydroxymethyl)Aminomethane) solution (Serva, Heidelberg, Germany) was added to each well. The absorbance reading was conducted at $540 \mathrm{~nm}$ wavelength with the use of microplate reader (ELx 800, BIO-TEK Instruments, Winooski, VT, USA) [18].

\subsubsection{Cell viability determination}

In the MTT and SRB assays, which are colorimetric tests, the value of absorbance is proportional to cell viability, determined by the correlation:

$$
\mathrm{V} \%=(\mathrm{Ab}-\mathrm{Am} / \mathrm{Ak}-\mathrm{Am}) \times 100 \%,
$$

where: $\mathrm{Ab}-$ absorbance of the test sample, Am - absorbance of the medium, Ak - absorbance of the control sample.
Cell viability ( $\mathrm{V} \%)$ was given as a percentage of cells in the test sample in relation to the control, which consisted of cells from the complete culture medium.

\subsection{Microbiological tests}

The tests were conducted on Candida albicans ATCC 90028, Streptococcus mutans ATCC 25175, Lactobacillus rhamnosus ATCC 9595 type strains. Colon-Forming Units per $\mathrm{ml}(\mathrm{CFU} / \mathrm{ml})$ and Minimum Inhibitory Concentration (MIC) $(\mu \mathrm{g} / \mathrm{ml})$ were used for determination. Experiments were carried out in triplicate.

\subsubsection{CFU determination}

From the culture of strains, a suspension of 0.5 McFarland density in a liquid Sabourada Bulion Brain Heart Infusion-BHI and MRS-de Man, Rogosa and Sharpe medium (BioMaxima S.A., Lublin, Poland) was prepared for C. albicans, S. mutans and L. rhamnosus, respectively [2], [4]. The so-prepared suspensions were incubated for $24 \mathrm{~h}$ with haemostatic agents with initial concentration of aluminium chloride equal to $1000 \mu \mathrm{g} / \mathrm{ml}$ at $37{ }^{\circ} \mathrm{C}$, in aerobic, anaerobic and microaerophilic conditions. Then, $100 \mu 1$ of the suspension was taken and a series of dilutions were made in $0.85 \% \mathrm{NaCl}$ in geometric progression $\left(10^{-1}-10^{-6}\right)$, and $100 \mu 1$ of the suspension was cultured onto each solid medium suitable for a given strain. The plates were incubated for $24 \mathrm{~h}$ at $37^{\circ} \mathrm{C}$ Heratherm IGS 100 incubator (Thermo Electron LED GmbH, Langenselboig, Germany) and then, the colonies were counted and the number of Colony-Forming Units per milliliter $(\mathrm{CFU} / \mathrm{ml})$ was determined according to the formula:

$\mathrm{CFU} / \mathrm{ml}=$ average colony count $\times$ dilution inverse $\times 10$.

\subsubsection{MIC determination}

The Sabourad Bulion, Brain Heart Infusion (BHI) and MRS (de Man, Rogosa and Sharpe) medium, in the amount of $100 \mu 1$, was placed in the wells of a 96-well plate for C. albicans, S. mutans and L. rhamnosus, respectively. After placing the haemostatic agents in the appropriate rows of the plate and diluting it in geometric progress, a range of concentrations from 500 $0.24 \mu \mathrm{g} / \mathrm{ml}$ was obtained. Then, $20 \mu \mathrm{l}$ of diluted microorganism suspension with 0.5 McFarland density in the Sabourad, BHI and MRS liquid medium for C. albicans, $S$. mutans and L. rhamnosus, respectively, was meas- 
ured into the plate wells, and the plate was incubated for $24 \mathrm{~h}$ at $37^{\circ} \mathrm{C}$ (aerobically, anaerobically and microaerophilically). After the period of incubation, $20 \mu \mathrm{l}$ of XTT (2,3-bis-(2-methoxy-4-nitro-5-sulfophenyl)-2H-tetrazolium-5-carboxanilide), (1 mg/ml, Sigma-Aldrich) was added, and the value of the MIC (Minimum Inhibitory Concentration), expressed in $\mu \mathrm{g} / \mathrm{ml}$, was read [2], [18].

\subsection{Statistical analysis}

Statistical analysis was conducted with the use of the Statistica 13.3 software (TIBCO Software Inc, Palo Alto CA, USA). The analysis of variable distribution normality was conducted with the use of the ShapiroWilk test. The non-parametric ANOVA KruskalWallis test was used to analyze the differences in cell viability in the test and control samples. The Student's $t$-test for the independent samples in relation to the variables was used to analyze the differences between $\mathrm{CFU} / \mathrm{ml}$ for microbial strains, $p<0.05$ was considered statistically significant.

\section{Results}

\subsection{In vitro cytotoxicity}

\subsection{1. $\mathrm{pH}$ determination}

All haemostatic agents were characterized by low $\mathrm{pH}$ in the range of 2-3. Among the extracts and their dilutions, the highest $\mathrm{pH}$ was measured for Alustat (foam), for which at a dilution of $1: 10, \mathrm{pH}$ was noted 4.2; for a dilution of $1: 20, \mathrm{pH}=4.6$, and at a dilution of $1: 40, \mathrm{pH}$ value was 5.04. The results of the $\mathrm{pH}$ measurement are presented in Table 2. However, in the negative control, which was the HDPE extract (1:5) and in the positive control SLS (0.01 and $0.05 \mathrm{mg} / \mathrm{ml})$, the $\mathrm{pH}$ values were unchanged and their value was identical to the full EMEM medium and was $\mathrm{pH}=7.39$. In the positive controls with SLS (0.2, $0.15 \mathrm{mg} / \mathrm{ml}$ ) the $\mathrm{pH}$ values were slightly higher (the highest $\mathrm{pH}=7.68$ ).

\subsubsection{Evaluation of cell morphology}

Microscopic evaluation of L929 cells $24 \mathrm{~h}$ after contact with all haemostatic agents being studied showed a slight change in the shape of cells, presence of heterochromatic, enlarged cell nuclei, decrease in the number of cells in divisions (Figs. 1a-7c). No cell lysis or damage to cell membrane, which were observed in the positive control (SLS solutions, 0.2-0.1 mg/ml), was found (Figs. 1, 8a-c). Cell morphology $24 \mathrm{~h}$ after contact with the extract from HDPE and in the control culture in the complete medium was normal (Fig. 1).

\subsubsection{MTT assay}

L929 cell viability after $24 \mathrm{~h}$ of incubation with extracts was drastically low for each dilution (1:5, $1: 10$ and 1:20) for both the agents containing $25 \%$ of $\mathrm{AlCl}_{3}$ (Alustat (liquid), Alustat (gel), Racestyptine) and the agents containing $20 \%$ of aluminium chloride (Alustat (foam), Alustin (liquid), Hemostat and 15\% Traxodent), and it did not exceed $1 \%$ for the $1: 5$ dilutions, a little over $1 \%$ for the $1: 10$ dilutions, while for the 1:20 dilutions it amounted to 3\% (Figs. 2A, B) The differences between all studied dressings were statistically significantly lower than the control (cells conducted the complete medium), however, very low absorbance readings made it impossible to compare the studied dressings (Figs. 2A, B). The negative control included in the study, namely, the extract from HDPE, did not cause a statistically significant decrease in cell viability in comparison with the control $(95.5 \%$ vs. $100 \%)$ which consisted of cells in the complete medium. Cell viability in the positive control, which included SLS solutions at concentrations $0.2 \mathrm{mg} / \mathrm{ml}, 0.15 \mathrm{mg} / \mathrm{ml}, 0.1 \mathrm{mg} / \mathrm{ml}$ and $0.05 \mathrm{mg} / \mathrm{ml}$, amounted to $8.9 \%, 18.8 \%, 37.9 \%$ and $75.5 \%$, respectively (Figs. 2A, B). The controls included in the study showed normal cell culture reactivity.

Table 2. $\mathrm{pH}$ values of diluted extracts from haemostatic.

Dilutions were made in the EMEM medium (Eagle's Minimum Essential Medium)

\begin{tabular}{|l|c|c|c|c|c|c|c|}
\hline & $\begin{array}{c}\text { Alustat } \\
\text { (liquid) }\end{array}$ & $\begin{array}{c}\text { Alustat } \\
\text { (gel) }\end{array}$ & $\begin{array}{c}\text { Alustat } \\
\text { (foam) }\end{array}$ & $\begin{array}{c}\text { Alustin } \\
\text { (liquid) }\end{array}$ & $\begin{array}{c}\text { Hemostat } \\
\text { (gel) }\end{array}$ & $\begin{array}{c}\text { Racestyptine } \\
\text { (liquid) }\end{array}$ & $\begin{array}{c}\text { Traxodent } \\
\text { (paste) }\end{array}$ \\
\hline $1: 10$ & 3.38 & 3.27 & 4.20 & 3.38 & 3.39 & 3.34 & 3.80 \\
\hline $1: 20$ & 3.71 & 3.69 & 4.60 & 3.78 & 3.81 & 3.68 & 4.00 \\
\hline $1: 40$ & 4.05 & 4.06 & 5.04 & 4.29 & 4.46 & 4.02 & 4.44 \\
\hline
\end{tabular}




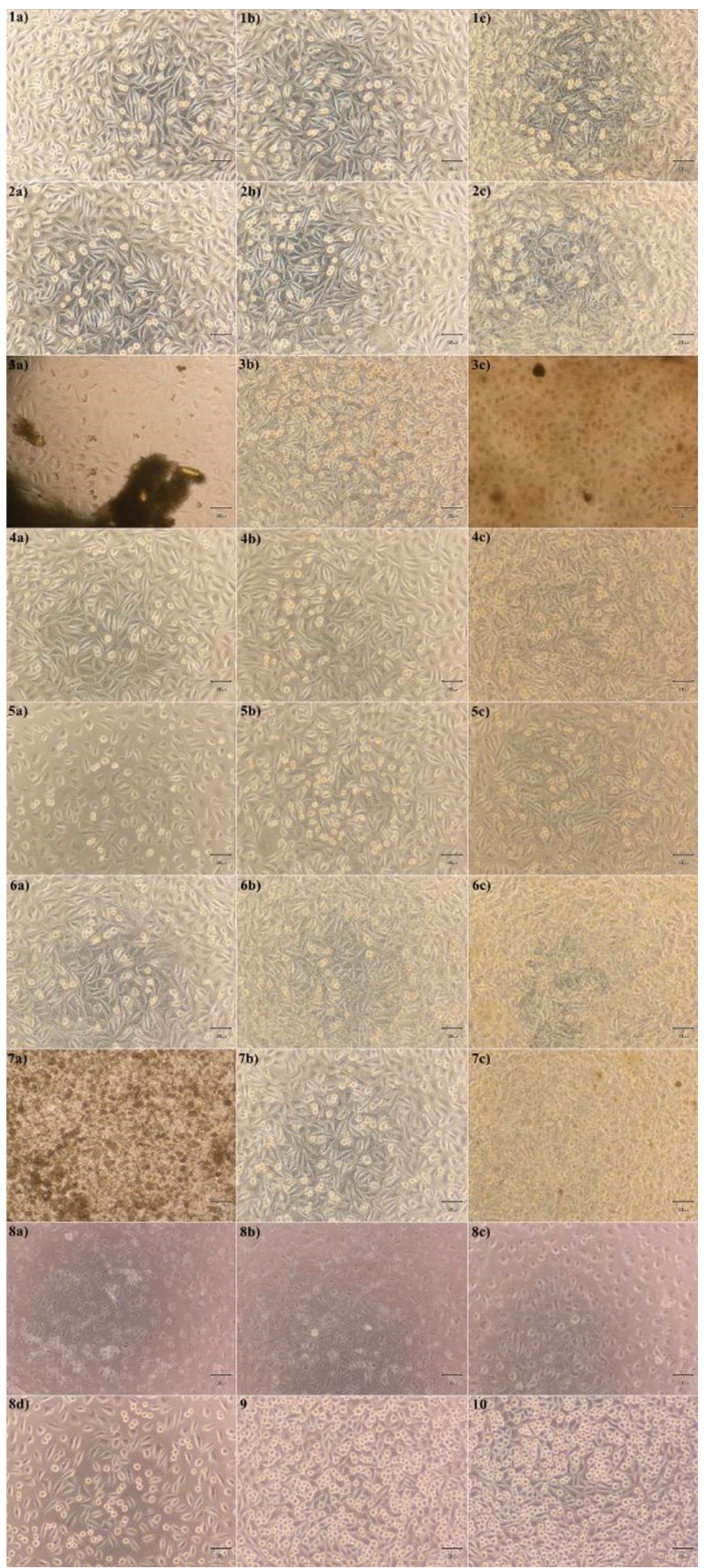

Fig. 1. Microscopic image of L929 cells after $24 \mathrm{~h}$ of incubation with extracts from haemostatic agents: $100 \%$ (a), 50\% (b) and 25\% (c); 1 - Alustat (liquid); 2 - Alustat (gel); 3 - Alustat (foam); 4 - Alustin (liquid); 5 - Racestyptine (liquid); 6 - Hemostat (gel); 7 - Traxodent (paste);

8 - positive control: extracts from SLS with concentrations a) $0.2 \mathrm{mg} / \mathrm{ml}$, b) $0.15 \mathrm{mg} / \mathrm{ml}$, c) $0.1 \mathrm{mg} / \mathrm{ml}$, d) $0.05 \mathrm{mg} / \mathrm{ml}$; 9 - negative control: $100 \%$ extract from HDPE; 10 - control culture. Magnification $100 \times$ 


\subsubsection{SRB assay}

Agents containing $25 \%$ of $\mathrm{AlCl}_{3}$ (Alustat (liquid), Alustat (gel), Racestyptine) strongly inhibited the viability of L929 cells (Fig. 2C). For the 1:10 dilution, cell viability was $37.6 \%$, for Alustat (liquid), a little less for its gel form (35.1\%) and it amounted to $31.9 \%$ for Racestyptine (Table 3 ). The difference in cell viability after contact with the Alustat (liquid) and Racestyptine was statistically significant ( $p=0.0206)$. For the 1:20 dilutions, cell viability after contact with agents containing $25 \%$ of aluminium chloride was similar: $45.2 \%$ for Alustat (liquid), $45.6 \%$ for Alustat (gel) and $41.3 \%$ for Racestyptine, and did not show differences in terms of statistics (Table 4). For the 1:40 dilutions in this group of dressings, cell viability amounted to $64.7 \%$ for Alustat (liquid), $58.4 \%$ for Alustat (gel) and $75.4 \%$ for Racestyptine, and the differences between cell viability were not statistically significant (Table 5). Cell viability after contact with the agents diluted in

Table 3. Values of statistical significance ( $p$ ) for multiple comparisons (bilateral);

1:10 dilution of extracts from haemostatic agents. ANOVA Kruskal-Wallis test, $p<0.05$ was considered statistically significant

\begin{tabular}{|l|c|c|c|c|c|c|c|}
\hline \multicolumn{1}{|c|}{$1: 10$} & $\begin{array}{c}\text { Alustat } \\
\text { (liquid) }\end{array}$ & Alustat (gel) & $\begin{array}{c}\text { Alustat } \\
\text { (foam) }\end{array}$ & $\begin{array}{c}\text { Alustin (liq- } \\
\text { uid) }\end{array}$ & $\begin{array}{c}\text { Hemostat } \\
\text { (gel) }\end{array}$ & $\begin{array}{c}\text { Racestyptine } \\
\text { (liquid) }\end{array}$ & $\begin{array}{c}\text { Traxodent } \\
\text { (paste) }\end{array}$ \\
\hline Alustat (liquid) & & 0.711148 & 0.793261 & 1.000000 & 0.821455 & 0.020642 & 0.003732 \\
\hline Alustat (gel) & 0.711148 & & 0.005787 & 1.000000 & 0.008947 & 1.000000 & 1.000000 \\
\hline Alustat (foam) & 0.793261 & 0.005787 & & 0.221681 & 1.000000 & 0.000135 & 0.000026 \\
\hline Alustin (liquid) & 1.000000 & 1.000000 & 0.221681 & & 0.252661 & 0.171166 & 0.040759 \\
\hline Hemostat (gel) & 0.821455 & 0.008947 & 1.000000 & 0.252661 & & 0.000303 & 0.000070 \\
\hline Racestyptine (liquid) & 0.020642 & 1.000000 & 0.000135 & 0.171166 & 0.000303 & & 1.000000 \\
\hline Traxodent (paste) & 0.003732 & 1.000000 & 0.000026 & 0.040759 & 0.000070 & 1.000000 & \\
\hline
\end{tabular}
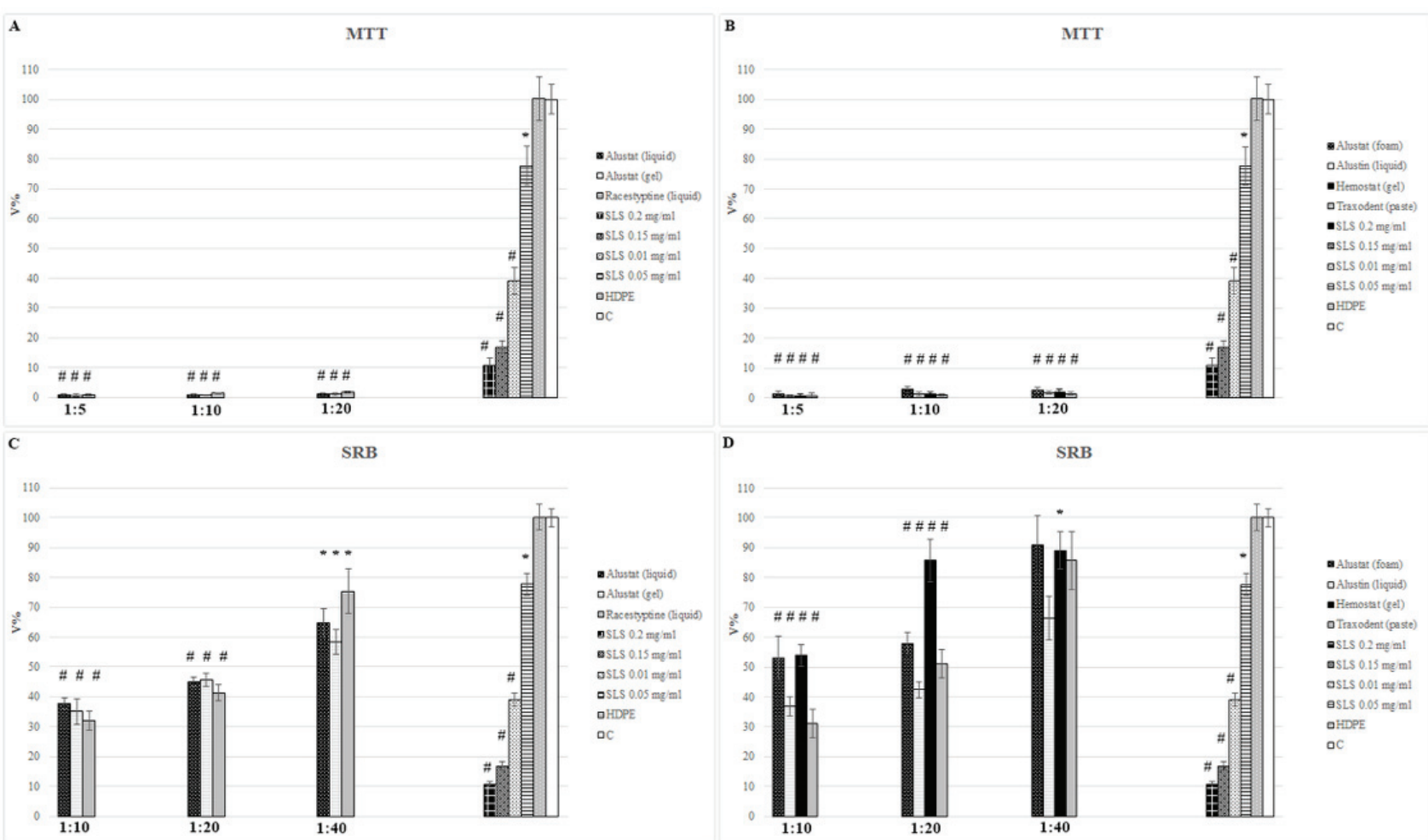

Fig. 2. L929 cell viability $24 \mathrm{~h}$ after the incubation with haemostatic agents in 1:5, 1:10, 1:20 and 1:40 dilutions in the MTT (A and B) and SRB (C and D) assay. Significant differences in the results depending on the applied assay are visible, both for the dressings containing $25 \%$ of $\mathrm{AlCl}_{3}(\mathrm{~A}, \mathrm{C})$ and those containing $20 \%$ and $15 \%$ (B, D). Positive control: SLS solutions; negative: extract (1:5) from HDPE; $\mathrm{C}$ - control culture. ANOVA Kruskal-Wallis test values $p$ for multiple comparisons,

$$
* p<0.05, \# p<0.0001 \text { with regard to control }
$$


a ratio of $1: 10,1: 20$ and 1:40 was statistically significantly lower as compared to the control culture conducted in the complete medium (Fig. 2C).

Agents containing $20 \%$ of $\mathrm{AlCl}_{3}$ (Alustat (foam), Alustin (liquid), Hemostat (gel) and $15 \%$ of $\mathrm{AlCl}_{3}$ (Traxodent) caused a decrease in the viability rate ranging from 30 to $53.8 \%$ at 1:10 dilution (Fig. 2D, Table 3). Cell viability rate was similar $(53.0 \%$ and $53.7 \%$ ) for Alustat (foam) and Hemostat, and it was lower and amounted to $36.8 \%$ and $30.0 \%$ in the case of Alustin (liquid) and Traxodent. The difference in cell viability after contact with Alustat (foam) and Traxodent was statistically significant ( $p=0.0407$ ). For the 1:20 dilutions, cell viability after contact with Alustat (foam) amounted to $57.8 \%$ and was lower, without a statistically significant difference, than after contact with Hemostat (85.7\%) (Table 4). Cell viability for Alustin (liquid) was $42.5 \%$, lower than in the case of Traxodent $(51.1 \%)(p=0.005)$, and it was the lowest among the agents diluted in a 1:20 ratio. The difference between cell viability after contact with Alustin (liquid) and Alustat (foam) was statistically significant

Table 4. Values of statistical significance ( $p$ ) for multiple comparisons (bilateral); 1:20 dilution of extracts from haemostatic agents ANOVA Kruskal-Wallis test, $p<0.05$ was considered statistically significant

\begin{tabular}{|l|c|c|c|c|c|c|c|}
\hline \multicolumn{1}{|c|}{$1: 20$} & $\begin{array}{c}\text { Alustat } \\
\text { (liquid) }\end{array}$ & $\begin{array}{c}\text { Alustat } \\
\text { (gel) }\end{array}$ & $\begin{array}{c}\text { Alustat } \\
\text { (foam) }\end{array}$ & $\begin{array}{c}\text { Alustin } \\
\text { (liquid) }\end{array}$ & $\begin{array}{c}\text { Hemostat } \\
\text { (gel) }\end{array}$ & $\begin{array}{c}\text { Racestyptine } \\
\text { (liquid) }\end{array}$ & $\begin{array}{c}\text { Traxodent } \\
\text { (paste) }\end{array}$ \\
\hline Alustat (gel) & 1.000000 & & 0.038510 & 0.817518 & 0.000035 & 0.376913 & 0.977574 \\
\hline Alustat (foam) & 0.018929 & 0.038510 & & 0.000006 & 1.000000 & 0.000001 & 1.000000 \\
\hline Alustin (liquid) & 1.000000 & 0.817518 & 0.000006 & & 0.000000 & 1.000000 & 0.005 \\
\hline Hemostat (gel) & 0.000012 & 0.000035 & 1.000000 & 0.000000 & & 0.000000 & 1.000000 \\
\hline Racestyptine (liquid) & 0.646877 & 0.376913 & 0.000001 & 1.000000 & 0.000000 & & 0.001838 \\
\hline Traxodent (paste) & 0.647128 & 0.977574 & 1.000000 & 0.005 & 1.000000 & 0.001838 & \\
\hline
\end{tabular}
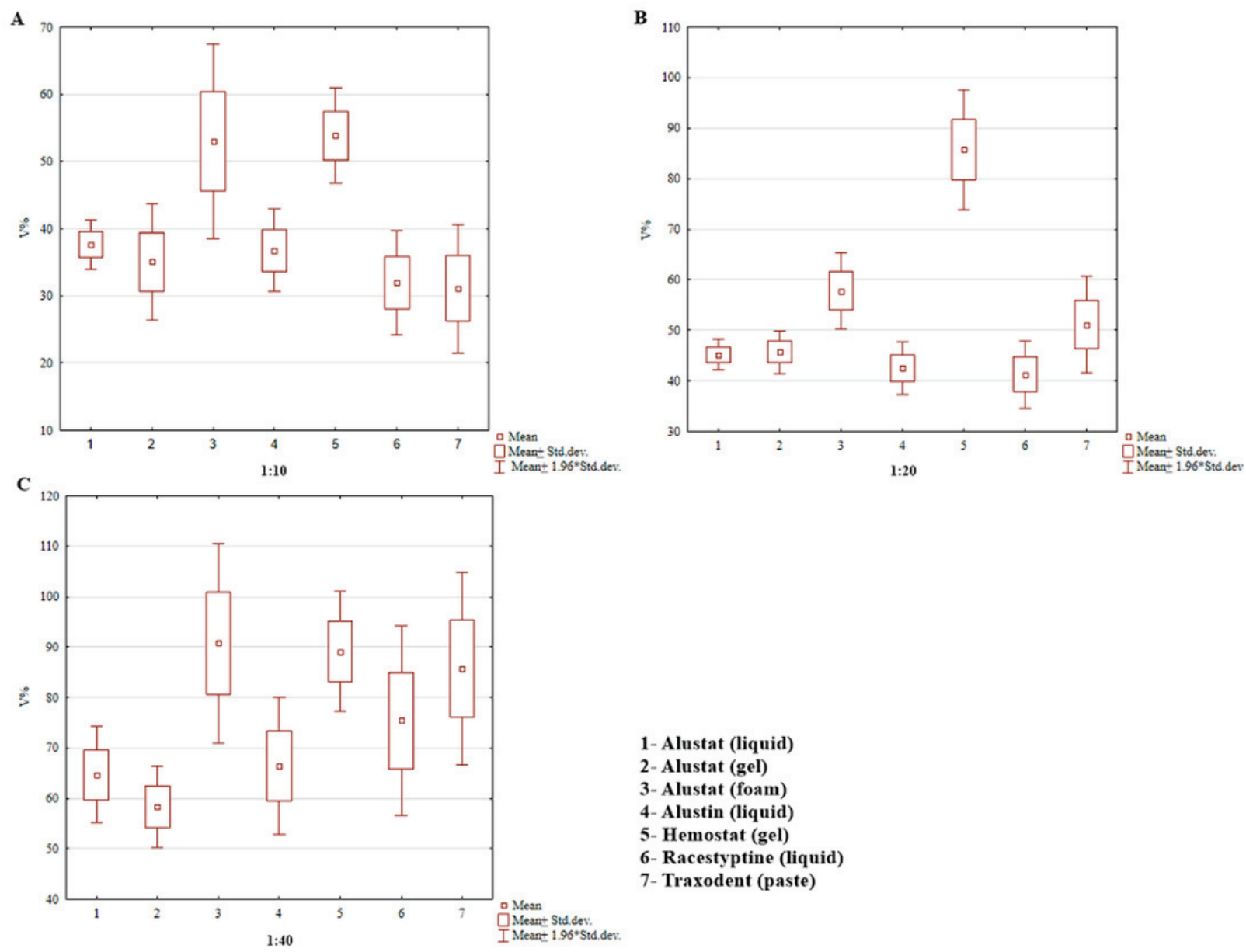

Fig. 3. L929 cell viability in the SRB assay $24 \mathrm{~h}$ after the incubation with haemostatic agents in dilutions: 1:10 (A), 1:20 (B) and 1:40 (C). ANOVA Kruskal-Wallis test, $p$ values for multiple comparisons are presented in Tables 3-5 
Table 5. Values of statistical significance ( $p$ ) for multiple comparisons (bilateral); 1:40 dilution of extracts from haemostatic agents. ANOVA Kruskal-Wallis test, $p<0.05$ was considered statistically significant

\begin{tabular}{|l|c|c|c|c|c|c|c|}
\hline \multicolumn{1}{|c|}{$1: 40$} & $\begin{array}{c}\text { Alustat } \\
\text { (liquid) }\end{array}$ & $\begin{array}{c}\text { Alustat } \\
\text { (gel) }\end{array}$ & $\begin{array}{c}\text { Alustat } \\
\text { (foam) }\end{array}$ & $\begin{array}{c}\text { Alustin } \\
\text { (liquid) }\end{array}$ & $\begin{array}{c}\text { Hemostat } \\
\text { (gel) }\end{array}$ & $\begin{array}{c}\text { Racestyptine } \\
\text { (liquid) }\end{array}$ & $\begin{array}{c}\text { Traxodent } \\
\text { (paste) }\end{array}$ \\
\hline Alustat (gel) & 1.000000 & & 0.000003 & 0.563778 & 0.000000 & 0.000892 & 0.000090 \\
\hline Alustat (foam) & 0.002394 & 0.000003 & & 0.009367 & 1.000000 & 0.858614 & 1.000000 \\
\hline Alustin (liquid) & 1.000000 & 0.563778 & 0.009367 & & 0.000307 & 1.000000 & 0.086519 \\
\hline Hemostat (gel) & 0.000038 & 0.000000 & 1.000000 & 0.000307 & & 0.272164 & 1.000000 \\
\hline Racestyptine (liquid) & 0.421417 & 0.000892 & 0.858614 & 1.000000 & 0.272164 & & 1.000000 \\
\hline Traxodent (paste) & 0.027269 & 0.000090 & 1.000000 & 0.086519 & 1.000000 & 1.000000 & \\
\hline
\end{tabular}

( $p=0.000006)$. For the 1:40 dilutions, cell viability rate after contact with Alustat (foam) and Hemostat (gel) was similar and amounted to $90.8 \%$ and $89.2 \%$ (Table 5). Cell viability rate of $85.7 \%$ was observed for Traxodent, and cell viability rate was the lowest for Alustin (liquid) among the agents diluted in a 1:40 ratio (66.4\%). Statistically significant difference was observed between cell viability after contact with Alustat (foam) and Alustin (liquid) ( $p=0.0094)$. Cell viability after contact with agents diluted in a ratio of $1: 10$, $1: 20$ and $1: 40$ was statistically significantly lower in comparison to the control culture conducted in the complete medium (Fig. 2D).

Among all studied dressings, the highest cell viability at 1:10 dilution was observed for Alustat (foam) and Hemostat (53.0\% and 53.7\%, respectively) and the results did not differ in terms of statistics (Fig. 3A, Table 3). Cell viability after contact with Hemostat was statistically significantly higher than after contact with Alustat (gel) $(35.1 \%)(p=0.00894)$, Racesteptine $(32.0 \%)$ $(p=0.0003)$ and Traxodent $(30.0 \%)(p=0.00007)$. Cell viability after contact with the remaining agents: Alustat (liquid) and Alustin (liquid) was lower than after contact with Hemostat (37.6\% and 36.8\%), but the difference was not statistically significant. On the other hand, cell viability after contact with Alustat (foam) amounted to $53.0 \%$ and was statistically significantly higher compared to cell viability after contact with Alustat (gel) $(58.4 \%, p=0.0058)$, Racesteptine ( $p=$ $0.000135)$ and Traxodent ( $p=0.000026)$.

The cell culture after contact with Hemostat showed the highest viability rate among the 1:20 dilutions $(85.7 \%)$ (Fig. 3B, Table 4). The value was statistically significantly higher in comparison with cell viability after contact with Alustat (liquid) (64.7\%) ( $p=0.000012)$, Alustat (gel) $(p=0.000035)$, Racestyptine (75.4\%) $(p=0.0000001)$ and Alustin (liquid) $(42.5 \%)(p=0.0000001)$. Only cell viability after contact with Alustat (foam) (57.8\%) and Traxodent (51.1\%) did not differ statistically from cell viability after contact with Hemostat.
The highest viability rate for the 1:40 dilutions was observed after cell contact with Hemostat (89.2\%), Alustat (foam) (90.8\%), and Traxodent (85.7\%), and it was slightly lower for Racestyptine (75.4\%); these differences, however, were not statistically significant (Fig. 3C, Table 5). Alustat (liquid) and Alustat (gel) showed stronger effect, causing a decrease in cell viability to $64.7 \%$ and $58.4 \%$, respectively, and these results were statistically significantly lower in comparison with the cells after contact with Alustat (foam) $(p=0.002394, p=0.000003)$, Hemostat (gel) $(p=0.000038, p=0.0000001)$ and Traxodent $(p=$ $0.027269, p=0.00009$ ). Alustin (liquid) caused a decrease in cell viability to $66.4 \%$, and the result was statistically significantly lower in comparison with the viability of cells after contact with Alustat (foam) $(p=0.009367)$ and Hemostat $(p=0.000307)$.

L929 cell viability after contact with the extract from HDPE, constituting the negative control, amounted to $97.9 \%$ and did not differ statistically from the blank test (cells conducted in the complete medium) and amounted to $100 \%$. (Fig. 1, Fig. 2C, D). Cell viability in the positive control, that is SLS solution at concentrations $0.2 \mathrm{mg} / \mathrm{ml}, 0.15 \mathrm{mg} / \mathrm{ml}, 0.1 \mathrm{mg} / \mathrm{ml}$ and $0.05 \mathrm{mg} / \mathrm{ml}$ amounted to $8.9 \%, 13.8 \%, 37.9 \%$ and $75.5 \%$, respectively (Fig. 2C, D. 8, Fig. 3). The negative and positive controls used in the study showed normal reactivity of the L929 cell culture.

\subsection{Microbiological tests}

\subsubsection{CFU determination}

The CFU/ml values for the studied microorganisms after the incubation with haemostatic agents are presented in Table 6. For Alustat (gel), Alustat (liquid), Hemostat and Alustin (liquid), no growth of the C. albicans, S. mutans oraz L. rhamnosus colonies was observed. The value of $\mathrm{CFU} / \mathrm{ml}$ for $C$. albicans and Alustat (foam) was $1.0 \times 10^{5}$ and was statistically 
Table 6. Values of colony forming units per $\mathrm{ml}(\mathrm{CFU} / \mathrm{ml})$ for the tested strains after contact with haemostatic agents. $* p<0.001-$ differences of statistic importance in relation to the control

\begin{tabular}{|l|c|c|c|}
\hline \multirow{2}{*}{ Medicament } & \multicolumn{3}{|c|}{ CFU $/ \mathrm{ml}$} \\
\cline { 2 - 4 } & C. albicans mean $\pm \mathrm{SD}$ & S. mutans mean $\pm \mathrm{SD}$ & L. rhamnosus mean \pm SD \\
\hline Alustat (liquid) & 0 & 0 & 0 \\
\hline Alustat (gel) & 0 & 0 & 0 \\
\hline Alustat (foam) & $1.01 \times 10^{5} * \pm 5.77 \times 10^{2}$ & 0 & 0 \\
\hline Alustin (liquid) & 0 & 0 & 0 \\
\hline Hemostat (gel) & 0 & 0 & 0 \\
\hline Racestyptine (liquid) & $5.0 \times 10^{2} * \pm 2.52$ & 0 & $2.3 \times 10^{3} \pm 2.89 \times 10^{1}$ \\
\hline Traxodent (paste) & $1.4 \times 10^{4} * 1.04 \times 10^{2}$ & $0.04 \times 10^{3}$ \\
\hline Control & $6.5 \times 10^{3} \pm 5.77 \times 10^{1}$ & $5.1 \times 10^{5} \pm 5.51 \times 10^{3}$ & $4.8 \times 10^{4} \pm 5.86 \times 10^{2}$ \\
\hline
\end{tabular}

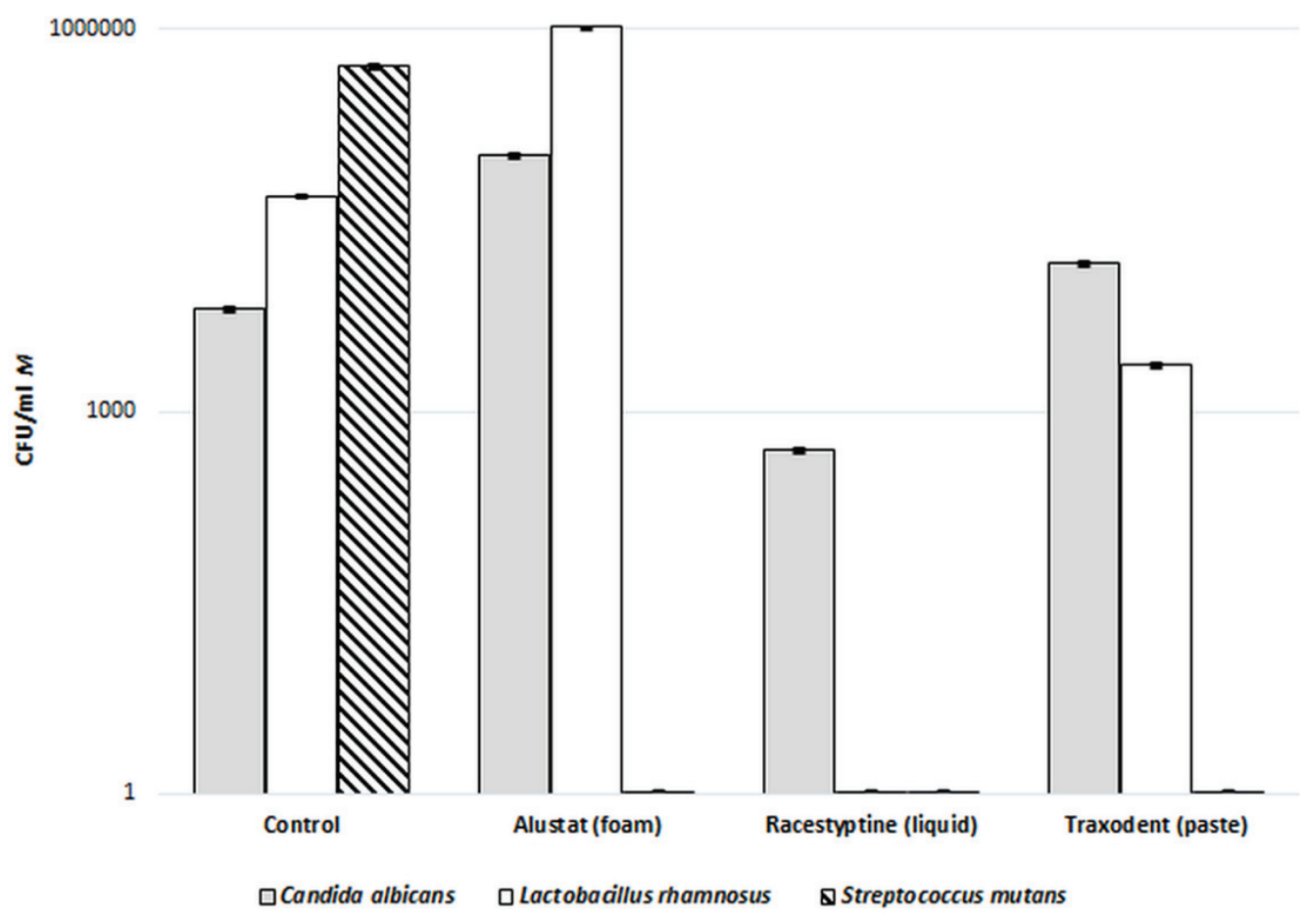

Fig. 4. CFU/ml values for the tested strains after $24 \mathrm{~h}$ incubation with quinosol-free haemostatic agents and for the control culture

significantly higher $(p=0.000000)$ than in the control $\left(6.5 \times 10^{3}\right)$, while for L. rhamnosus it was $1.05 \times 10^{6}$, and it was also statistically significantly higher than in the control $\left(4.8 \times 10^{4}\right)(p=0.000000)$ (Fig. 4, Table. 6). For Racestyptine (liquid), the value of $\mathrm{CFU} / \mathrm{ml}$ for $C$. albicans was $5 \times 10^{2}$, and was statistically significantly lower than in the control $\left(6.5 \times 10^{3}\right)(p=0.000000)$; colony growth was not observed in the case of $S$. $m u$ tans and L. rhamnosus. The observed value of CFU $/ \mathrm{ml}$ for Traxodent was $1.4 \times 10^{4}$ for C. albicans, and the result was statistically significantly higher in comparison with the control $(p=0.000000)$, and the value of CFU $/ \mathrm{ml}$ for L. rhamnosus was $2.3 \times 10^{3}$, and was statistically significantly lower than in the control $(p=0.000000)$. All tested haemostatic agents inhibited the growth of the S. mutans colony. The values of the minimum inhibitory concentration of quinosol-free agents (Alustat (foam), Racestyptine and Traxodent) are presented in Fig. 4.

\subsubsection{MIC determination}

The values of MIC (Minimum Inhibitory Concentration) for haemostatic agents in relation to the C. albicans, S.mutans and L. rhamnosus strains are presented in Table 7. The MIC values of Alustat (liquid), Alustat (gel), Alustin (liquid), Hemostat (gel) and Racestyptine (liquid) was $62.5 \mu \mathrm{g} / \mathrm{ml}$ for the C. albicans strain, whereas in the case of Alustat (foam) and Traxodent it amounted to $500 \mu \mathrm{g} / \mathrm{ml}$. The MIC values for the S. mutans strain amounted to $500 \mu \mathrm{g} / \mathrm{ml}$ except for Alustin (liquid) and Hemostat, for which the MIC value 
was above $500 \mu \mathrm{g} / \mathrm{ml}$. In the case of Alustat (foam) and Traxodent, the MIC value for the L. rhamnosus strain was above $500 \mu \mathrm{g} / \mathrm{ml}$, and for the remaining agents $-500 \mu \mathrm{g} / \mathrm{ml}$.

Table 7. Values of minimum inhibitory concentration (MIC) for the tested strains after contact with haemostatic agents

\begin{tabular}{|l|c|c|c|}
\hline \multirow{2}{*}{\multicolumn{1}{|c|}{ Medicament }} & \multicolumn{3}{|c|}{ MIC $(\mu \mathrm{g} / \mathrm{ml})$} \\
\cline { 2 - 4 } & C. albicans & S. mutans & L. rhamnosus \\
\hline Alustat (liquid) & 62.5 & 500 & 500 \\
\hline Alustat (gel) & 62.5 & 500 & 500 \\
\hline Alustat (foam) & 500 & 500 & $\uparrow 500$ \\
\hline Alustin (liquid) & 62.5 & $\uparrow 500$ & 500 \\
\hline Hemostat (gel) & 62.5 & $\uparrow 500$ & 500 \\
\hline Racestyptine (liquid) & 62.5 & 500 & 500 \\
\hline Traxodent (paste) & 500 & 500 & $\uparrow 500$ \\
\hline
\end{tabular}

\section{Discussion}

Haemostatic materials used to quickly stop bleeding should not affect or should only slightly affect the cells of the tissues with which they come into contact, and the disturbances of which may also result in systemic disorders. The available haemostatics are, therefore, not fully biocompatible with the gingival tissue [7]. Determining cytotoxicity against cells in in vitro cultures constitutes an important introduction to the broadly-understood toxicological studies, necessary for the determination of the proper effects and safety of a given medication. The application of cell models in toxicological in vitro studies has many advantages, such as: the quickness and easiness of studying cellular and molecular processes, repeatability and possibility of using small amounts of the tested substances. In vitro studies are screening tests and enable varied evaluation of materials in terms of the cytotoxic and bactericidal effects. Various cellular tests are used for quantitative determination of the cytotoxic activity of chemotherapeutic compounds. One of the methods of assessing biocompatibility are in vitro cytotoxicity tests, conducted on normal mouse fibroblasts of line L929 and Balb/3T3 [19].

The MTT and SRB assays are commonly used to assess cytotoxicity. Both tests are used to measure cell viability, however, the principles of how they work are different. The MTT assay is based on the measurement of the activity of succinate dehydrogenase, which converts yellow tetrazolium salt to violet formazan derivative in the mitochondrion of live cells. The result of the reaction is proportional to the amount of live cells, which is expressed by their viability [11]. The SRB assay consists in precipitating cell proteins in an acidic environment and staining them with purple rhodamine. Absorbance measured in this test is proportional to the mass of cells, expressed in their viability [18].

The results of the MTT assay obtained by us showed that L929 cell viability was strongly decreased after the incubation with all diluted haemostatic agents. The results are consistent with the results of the studies conducted with the use of the MTT assay by Nowakowska et al. [13] on human fibroblasts from gingiva subjected to a 24-hour-long incubation with Alustat (gel), Alustin (liquid), Hemostat (gel) and Racestyptine (liquid). The authors of the paper also tested the cytotoxicity of haemostatic agents after much shorter incubation time (3, 5 and $10 \mathrm{~min}$.), and the obtained results indicated much higher rate of cell viability than after 24-hour-long incubation [13]. In vitro studies conducted by Kopač et al. [9] on normal human keratinocytes from the oral cavity and pulomonary fibroblasts of V-79 hamster also showed cytotoxic effect of haematic agents on the basis of the results of the MTT assay [9], [13]. In addition, Kopač et al. [10] demonstrated changes on morphological and ultrastructural level in the cells of rat keratinocytes from the gingiva after contact with haemostatic agents.

However, the studies conducted by us demonstrated a significant difference between the assessment of L929 cell viability conducted with the use of the MTT assay and the SRB assay, despite higher dilution of the agents, which is most likely associated with the principles of how these tests work. Cell viability in the positive and negative control as well as in the complete medium (blank test) was practically identical in the MTT and SRB assay, which may indicate that the result of the MTT test was falsely understated, most likely due to the low $\mathrm{pH}$ of the tested astringents. Importantly, the results of the SRB - but not MTT - assay were consistent with the microscopic assessment of cells after the incubation with haemostatic agents.

The results which we obtained in the SRB assay showed the weakest cytotoxic effect at 1:10 dilution of haemostatic agents for Hemostat and Alustat (foam), and the difference between the two agents was not statistically significant. When the agents were diluted in a 1:20 ratio, the highest cell viability was observed for Hemostat; the result, however, did not differ statistically from cell viability after the incubation with Traxodent and Alustat (foam). When the agents were diluted in a 1:40 ratio, the highest cell viability was yet again observed for Hemostat as well as for Traxo- 
dent, Alustat (foam) and Racestyptine, without statistical differences between the agents. The conducted studies showed that after a 24-hour-long incubation with L929 cells, Hemostat had the mildest effect among the assessed agents. Alustat (foam) and Traxodent, followed by Racestyptine, also showed weaker cytotoxic effect than the other assessed agents.

On the other hand, the lowest cell viability for each dilution was observed for the dental agents with the highest concentration of $\mathrm{AlCl}_{3}$ (25\%): Alustat (liquid), Alustat (gel) and Alustin (liquid) which contains 20\% of aluminium chloride. These results indicate that their cytotoxic effect was the strongest in comparison with the other dental agents tested. In the case of Alustat (liquid) and Alustat (gel), the cytotoxic effect can be potentially associated with the high content $(25 \%)$ of aluminium chloride; however, considering Alustin, in which the content of $\mathrm{AlCl}_{3}(20 \%)$ is the same as it is in Hemostate, while their impact of cell viability is different, it should be assumed that the cytotoxic effect of the preparation is associated with the additional substances which they contain. The decreased cell viability after contact with all preparation may result from low $\mathrm{pH}$ of the tested preparation, which was below $\mathrm{pH}=5.0$, even after being diluted 40 times. Currently, astringents containing $\mathrm{AlCl}_{3}$ are among the most commonly applied astringents with the gentlest effect [20].

The results which we have obtained so far show that the studied haemostatic agents show cytotoxic effect in L929 cell culture, causing a decrease in cell viability below $30 \%$; however, it primarily pertains to the inhibition of culture growth, without causing cell lysis [20]. The studies conducted by us showed that the actual cytotoxic effect of the tested dental agents was significantly smaller than one might think based on the results obtained in the MTT assay. To the best of our knowledge, dental haemostatic agents have not been tested with the use of the SRB assay so far.

An increasing number of studies indicate that the MTT assay, commonly believed to be the gold standard in the assessment of cell viability both in the case of biomaterial studies and a number of chemical substances, has its limitations, and the results obtained in it may be falsely understated or overstated [21]. In a study conducted by Plumb et al. [15] it was shown that absorbance in the MTT assay may be decreased even 10 times in $\mathrm{pH}=3.5$. The authors indicate that it might be caused by the changes which occur in the MTT structure under reducing conditions [15], [23]. Furthermore, Wang et al. [23] showed, that in strong acidic solution cationic MTT formazan is formed, which results in decrease of absorption at $575 \mathrm{~nm}$ wave- length. Authors also proposed a mechanistic explanation of this reaction and showed how absorption peak dependence on $\mathrm{pH}$ value [23].

In addition, researchers also indicate changes in cell metabolism occurring under the influence of low $\mathrm{pH}$, which may also pertain to the decrease in the activity of succinate dehydrogenase [17]. In a study conducted by Shi et al. [17], it was demonstrated that the values of cell viability assessed with the use of the MTT assay within the range of $\mathrm{pH}=7.8-5.5$ were decreased for BEAS-2B cell line (human bronchial epithelium cells), but not for A549 cell line (human lung cancer cells [17]. In turn, in a study conducted by Jo et al. [8], the authors suggest that falsely overstated absorbance in the MTT assay may be caused by nonspecific, extra-mitochondrial MTT reduction occurring under the conditions of an increased NADH concentration after the incubation of human primary glioma cells as well as U87MG and U373 MG glioma cells in the presence of ethyl alcohol [8]. It seems that the change in the metabolic activity of cells under the influence of low $\mathrm{pH}$, at which the results of the MTT assay may depend, may be specific for a given cell line. What is more, researchers also indicate numerous possible interferences of the MTT assay caused by the tested compounds. Currently, researchers indicate that the SRB assay has a number of advantages, such as increased repeatability, independence from cell metabolism and the lack of sensitivity to the interferences caused by the tested compounds, which is reflected in the fact that the SRB assay is recommended by the NCI (National Cancer Institute) in the USA in preclinical screening tests [21].

The microbiological studies conducted by us demonstrated that all analyzed agents showed complete reduction of the value of $\mathrm{CFU} / \mathrm{ml}$ with regard to $S$. mutans, despite high values of the minimum inhibitory concentration $(500 \mu \mathrm{g} / \mathrm{ml})$. On the other hand, Alustat (gel) and Alustat (liquid) completely inhibited the growth of $C$. albicans, $S$. mutans and L. rhamnosus. In the case of Alustat (gel) and Alustat (liquid) the lowest MIC values $(62.5 \mu \mathrm{g} / \mathrm{ml})$ were shown for the C. albicans strain. Alustat (foam) did not show antimicrobial activity against $C$. albicans and $L$. rhamnosus, but it was active against $S$. mutans. Alustin (liquid) and Hemostat showed complete reduction of the value of $\mathrm{CFU} / \mathrm{ml}$ of all analyzed strains despite high MIC values. Alustat (foam) and Traxodent, which caused higher colony growth in comparison with the control, showed the least effectiveness against $C$. albicans and L. rhamnosus. Moreover, Alustat (foam) also did not show antimicrobial activity against $L$. rhamnosus, for which $\mathrm{CFU} / \mathrm{ml}$ was higher than in the control. Agents containing qui- 
nosol showed antimicrobial activity against all microorganisms tested in the study. The ones which did not contain it were active only against the Streptococcus mutans strain. Few studies so far have demonstrated antimicrobial haemostatic activity of dental agents. A study conducted by Hsu et al. [6] demonstrated antimicrobial properties of haemostatic agents, including also Traxodent and Racestyptine, among others also against $S$. mutans and $C$. albicans, for which the MIC value was $1.6 \%(\% \mathrm{v} / \mathrm{v})$. The authors of the study [6] suggest that the property is associated with the presence of both active substances and preservatives in the agents and also results from their low $\mathrm{pH}$.

\section{Conclusions}

The obtained results showed varied cytotoxic effect of haemostatic agents on fibroblasts as well as their different antimicrobial properties. The conducted studies show that viability of L929 cells obtained in the SRB assay is more reliable than that obtained in the MTT assay, and the former is preferred in the case of the assessment of biocompatibility of haemostatic agents with low $\mathrm{pH}$.

\section{Acknowledgements}

The study was conducted as part of the ST.B080.17.025 research project at Wroclaw Medical University, Wrocław, Poland. The authors acknowledge heads of departments for enabling studies: prof. Piotr Dzięgiel from Department of Human Morphology and Embryology, Division of Histology and Embryology and prof. Grażyna Gościniak from Department and Division of Microbiology, Wroclaw Medical University, Wrocław, Poland.

\section{Author contributions}

The preparation of the research program: M.S., A.R, M.P. J.N. and M.D..; The execution of research: M.S. A.R., M.P., J.N; The statistical analysis: M.S. A.R., M.P.; The interpretation of data: M.S., A.R., M.P., J.N., M.D.; Preparation of the manuscript: M.S., A.R., M.P., M.D, B.Z., K.W.; Obtain financing: M.S., and Z.R. All authors have read and agreed to the published version of the manuscript.

\section{Conflicts of interest}

The authors declare no conflict of interest.

\section{References}

[1] Al Hamad K.Q., Azar W.Z., Alwaeli H.A., SAid K.N., A clinical study on the effects of cordless and conventional retraction techniques on the gingival and periodontal health, J. Clin. Periodontol., 2008, 35, 105, 3-8.

[2] Balouiri M., Sadiki M., Ibnsouda S.K., Methods for in vitro evaluating antimicrobial activity: A review, J. Pharm. Anal., 2016, 6, 71-9.

[3] de Oliveira Bernades K., Hilgert L.A., Ribeiro A.P.D., Garcia F.C.P., Pereira P.N.R., The influence of hemostatic agents on dentin and enamel surfaces and dental bonding: $A$ systematic review, J. Am. Dent. Assoc., 2014, 145, 1120-1127.

[4] DOBRZYŃSKi M., PAJĄCZKOWSKA M., NOWICKA J., JAWORSKI A., Kosior P., Szymonowicz M. et al., Study of Surface Structure Changes for Selected Ceramics Used in the CAD/CAM System on the Degree of Microbial Colonization, in Vitro Tests, Biomed. Res. Int., 2019, 1-13.

[5] Hansen P.A., Tira D.E., BARLow J., Current methods of finish-line exposure by practicing prosthodontists, J. Prosthodont., 1999, 8, 163-70.

[6] Hsu B., Lee S., Schwass D., Tompkins G., Antimicrobial activity of chemomechanical gingival retraction products, J. Am. Dent. Assoc., 2017, 148, 493-499.

[7] Jaroszewska-WójCicka A., NowakowsKa D., Cytotoksyczność materiałów stosowanych $w$ protetyce stomatologicznej-przeglad piśmiennictwa. Cytotoxicity of dental materials used in prosthodontics. A literature review*, Protet. Stomatol., 2016, 66, 295-306 (in Polish).

[8] Jo H.Y., Kim Y., PARK H.W., MoOn H.E., BAE S., KIM J. et al., The Unreliability of MTT Assay in the Cytotoxic Test of Primary Cultured Glioblastoma Cells, Exp. Neurobiol., 2015, 24, 235-245.

[9] KopaC I., Viability of fibroblasts in cell culture after treatment with different chemical retraction agents, 1993, 98-104.

[10] KopAC I., STERLE M., MARION L., Electron microscopic analysis of the effects of chemical retraction agents on cultured rat keratinocytes, J. Prosthet. Dent., 2002, 87 (1), 51-56.

[11] Mosmann T., Rapid colorimetric assay for cellular growth and survival: Application to proliferation and cytotoxicity assays, J. Immunol. Methods, 1983, 65, 55-63.

[12] Moraes Melo Neto C.L., Borges JR H.F., Firmino DE Souza Y., SAntin G.C., SABio S., Comparison between aluminum chloride and tetryzoline hydrochloride for control of vertical gingival displacement and crevicular fluid, Rev. Odontol. UNESP, 2017, 46 (4), 220-226.

[13] Nowakowska D., SaczKo J., Kulbacka J., ChoromańsKa A., Dynamic oxidoreductive potential of astringent retraction agents, Folia Biol. (Praha), 2010, 56, 263-268.

[14] Nowakowska D., SACZKo J., KulBacka J., ChoromańsKa A., RASZEWSKI Z., Cytotoxic potential of vasoconstrictor experimental gingival retraction agents - in vitro study on primary human gingival fibroblasts, Folia Biol. (Czech Republic), 2012, 58, 37-43.

[15] Plumb J.A., Milroy R., Kaye S.B., Effects of the pH Dependence of 3-(4,5-Dimethylthiazol-2-yl)-2,5-diphenyltetrazolium Bromide-Formazan Absorption on Chemosensitivity Determined by a Novel Tetrazolium-based Assay, Cancer. Res., 1989, 49, 4435-4440.

[16] Safari S., Vossoghi SheshKalani M., Vossoghi SheShKalani M., Hoseini Ghavam F., Hamedi M., Gingival Retraction Methods for Fabrication of Fixed Partial Denture: Literature Review, J. Dent. Biomater., 2016, 3, 205-213. 
[17] Shi Q., MaAs L., Veith C., VAN Schooten F.J., Godschalk R.W., Acidic cellular microenvironment modifies carcinogen-induced DNA damage and repair, Arch. Toxicol., 2017, 91, 2425-2441.

[18] Skehan P., Storeng R., Scudiero D., Monks A., MCMAHON J., Vistica D. et al., New colorimetric cytotoxicity assay for anticancer-drug screening, J. Natl. Cancer Inst., 1990, 82, 1107-1112.

[19] SZYMONOWiCZ M., RYBAK Z., FRACZEK-SZCZYPTA A., Paluch D., RusaK A., Nowicka K. et al., Haemocompatibility and cytotoxic studies of non-metallic composite materials modified with magnetic nano and microparticles, Acta Bioeng. Biomech., 2015, 17, 49-58.

[20] TARighi P., Khoroushi M., A review on common chemical hemostatic agents in restorative dentistry, Dent. Res. J. (Isfahan), 2014, 11, 423-428.

[21] Van Tonder A., Joubert A.M., Cromarty A.D., Limitations of the 3-(4,5-dimethylthiazol-2-yl)-2,5-diphenyl-2H- -tetrazolium bromide (MTT) assay when compared to three commonly used cell enumeration assays, BMC Res. Notes, 2015, 8, 1-10.

[22] Von Arx T., Jensen S.S., HÄnni S., Schenk R.K., Haemostatic agents used in periradicular surgery: An experimental study of their efficacy and tissue reactions, Int. Endod. J., 2006, 39, 800-808.

[23] Wang X.-D., Deng R.-C., Liu Y., Li B., Ho S.-H., XiaO Z.-P., Modification of MTT Assay for Precision and Repeatability and Its Mechanistic Implication, Asian J. Chem., 2014, 26, 8015-8018.

[24] WoJda S., SAJEwicz E., Influence of dental materials on hardness and Young's modulus of the surface layers of tooth enamel formed as a result of friction, Acta Bioeng. Biomech., 2019, 21 (1), 129-139.

[25] Yalçin M., BarUtcigil Ç., UMar I., BozKuRT B.S., HaKKi S.S., Cytotoxicity of hemostatic agents on the human gingival fibroblast, Eur. Rev. Med. Pharmacol. Sci., 2013, 17, 984-988. 